\title{
UTERINE COLLAGENASE AND COLLAGEN IN YOUNG AND AGEING RABBITS
}

\author{
R. R. MAURER* AND R. H. FOOTE \\ Department of Animal Science, Cornell University, \\ Ithaca, N.Y. 14850, U.S.A.
}

(Received 12th January 1972, accepted 17th March 1972)

\begin{abstract}
Summary. Collagenase activity was measured 66 to $75 \mathrm{hr}$ after parturition in does at 34, 167 and 204 weeks of age. Uteri of ageing does contained less collagenase than those of young does. Uterine collagen content tended to increase with age. At Day 12 of pregnancy, uterine acid-soluble collagen was higher in does 174 weeks old than in does at 38 weeks of age.
\end{abstract}

Tissue collagen tends to increase with age. Both an increase and a change in the configuration of uterine collagen have been reported in the ageing rat (Burack, Wolfe, Lansing \& Wright, 1941; Kao \& McGavack, 1959; Finn, Fitch \& Harkness, 1963; Schaub, 1964/65). A decrease in the activity of collagenase and other proteases capable of degrading collagen was also reported (McGavack \& Kao, 1963; Schaub, 1964, 1964/65, 1965).

This investigation was conducted to examine changes in uterine collagen and collagenase activity in ageing female rabbits with declining reproductive ability.

Fifteen parous does were divided into three groups of five, averaging 34, 167 and 204 weeks of age and averaging one, nine and twenty-four previous litters, respectively. The does were killed and exsanguinated between 66 and $75 \mathrm{hr}$ after parturition. In preliminary trials, this was found to be the time of highest collagenase activity. Woessner (1962) found the peak of collagen degradation in the involuting rat uterus to be between 48 and $72 \mathrm{hr}$ after parturition. The uteri were removed and excess fluids were squeezed out before weighing. To measure collagenase content, each horn was cut longitudinally along the mesenteric and antimesenteric region and a 5-g (wet weight) sample was removed, minced and homogenized for $10 \mathrm{~min}$ with $30 \mathrm{ml} 0.01 \mathrm{M}$-calcium acetate (according to Kit 08001-8300, Mann Research Laboratories). The homogenate was centrifuged at $15,000 \mathrm{~g}$ for $15 \mathrm{~min}$ and the supernatant was decanted and filtered into a measuring cylinder. Collagenase activity was determined according to the method of Wünsch \& Heidrich (1963) using a synthetic chromophore, acyl-pentapeptide, 4-phenyl-azo-benzyloxycarbonyl-L-prolyl-Lleucyl-glycyl-L-prolyl-D-arginine dihydrate (Mann Research Laboratories). The assay was conducted at $37^{\circ} \mathrm{C}$ and a $\mathrm{pH}$ of $7 \cdot 1$. These conditions were chosen

* National Institute of Environmental Health Sciences, P.O. Box 12233, Research Triangle Park, N.C. 27709, U.S.A. 
to represent the optimum based upon preliminary enzyme activity studies conducted over a temperature range of 27 to $75^{\circ} \mathrm{C}$ and with $\mathrm{pH}$ varying from 3.5 to $10 \cdot 7$. The importance of $\mathrm{Ca}^{++}$was shown by the fact that the addition of 1 m-ethylenediamine tetraacetic acid (EDTA), which binds $\mathrm{Ca}^{++}$ions, reduced the activity of the uterine extract tenfold. Mandl, MacLennan \& Howes (1953) have reported that $\mathrm{Ca}^{++}$ions are necessary for collagenase activity. Cysteine, at $10^{-3} \mathrm{M}$, stimulated activity slightly whereas a $1-\mathrm{M}$ concentration had no effect. These properties are similar to those reported for collagenase in rat uteri by Jeffrey \& Gross (1970) and Ryan \& Woessner (1971) and in Cl. histolyticum (Mandl et al., 1953). In addition, our uterine homogenates were found to have collagenase activity when collagen from bovine Achilles tendon was used as the

TABLE 1

$$
\begin{gathered}
\text { COLLAGENASE AGTIVITY OF DIFFERENT AGED DOES AFTER } \\
\text { PARTURITION }
\end{gathered}
$$

\begin{tabular}{|c|c|c|c|c|}
\hline \multirow{2}{*}{$\underset{(\text { weeks })}{\text { Age }}$} & \multirow{2}{*}{$\begin{array}{c}\text { No. of } \\
\text { previous } \\
\text { litters }\end{array}$} & \multicolumn{3}{|c|}{ Uterine collagenase } \\
\hline & & $\begin{array}{c}\text { Specific activity } \\
(\mu \mathrm{mol} / \mathrm{min} / \mathrm{mg} \\
\left.\text { protein }, \times 10^{-3}\right)\end{array}$ & $\begin{array}{c}\text { Wet weight } \\
(\mu \text { mollg } \\
\text { uterine tissue })\end{array}$ & $\begin{array}{c}\text { Dry weight } \\
(\mu \mathrm{mol} / \mathrm{g} \\
\text { uterine tissue) }\end{array}$ \\
\hline $\begin{array}{r}34 \\
167 \\
204\end{array}$ & $\begin{array}{r}1 \pm 0 \\
9 \pm 2 \\
24 \pm 4\end{array}$ & $\begin{array}{l}2 \cdot 8 \pm 0 \cdot 2 \\
2 \cdot 6 \pm 0 \cdot 4 \\
2 \cdot 2 \pm 0.2^{*}\end{array}$ & $\begin{array}{l}1.6 \pm 0.2 \\
1.7 \pm 0.3 \\
1.4 \pm 0.1\end{array}$ & $\begin{array}{r}9 \cdot 8 \pm 1 \cdot 1 \\
10 \cdot 4 \pm 0.9 \\
8 \cdot 0 \pm 0.2\end{array}$ \\
\hline
\end{tabular}

The animals in the three age groups (average of five does/group) were killed 72,66 and $75 \mathrm{hr}$ after parturition.

Values expressed as means \pm S.E.

* Differs significantly from other means in the same column $(P<0.05)$.

substrate (Mandl et al., 1953). The protein content of the uterine extracts was determined according to the technique of Lowry, Rosebrough, Farr \& Randall (1951).

The collagen content of the uteri of the same fifteen does which were used for collagenase studies and of the uteri from six additional 12-day pregnant does was determined. Each uterine sample was weighed (wet weight), freeze-dried, desiccated, reweighed (dry weight) and separated into alkaline- and acidsoluble collagen. The alkaline-soluble fraction was extracted according to the method of Kao \& McGavack (1959), and the acid-soluble fraction according to the method of Fitch, Harkness \& Harkness (1955). Each extract was analysed for hydroxyproline content by the method of Prockop \& Udenfriend (1960). The hydroxyproline content was multiplied by $7 \cdot 46$ to give the collagen content (Neuman \& Logan, 1950).

The uterine collagenase activity in does of different age groups is shown in Table 1. The oldest does had the lowest uterine collagenase, with a significant difference $(P<0.05)$ in specific activity. This lower uterine collagenase could result in less of the collagen being broken down. The enzymes responsible for uterine involution are activated by progesterone withdrawal (Goodall, 1965, 1966). Maurer \& Foote (1972) found less progesterone in the ovarian venous blood of old pregnant does. This, in turn, might affect the activation of proteolytic enzymes. Oestrogens also can inhibit uterine involution but the effect 
appears to be one of inhibiting collagen breakdown rather than a direct one on the enzyme concentration (Woessner, 1969).

The alkaline- and acid-soluble collagen contents of the uteri in post-partum and 12-day pregnant does of differing ages are presented in Table 2. In the postpartum animals, the old does had significantly more alkaline-soluble collagen $(P<0.05)$. Mean acid-soluble and total collagen values were highest for the oldest does also, but animal variability was very great in this age group.

The 12-day pregnant ageing does (Table 2$)$ had a higher $(P<0.05)$ acidsoluble collagen content than the young females. Other comparisons were not statistically significant $(P>0 \cdot 10)$. The tendency for acid-soluble and total collagen content to increase in the ageing female rabbit is in agreement with earlier findings in the mouse and rat (Kao \& McGavack, 1959; Finn et al., 1963; Schaub, 1964/65).

TABLE 2

ALKALINE- AND ACID-SOLUBLE UTERINE GOLLAGEN CONTENT OF POST-PARTUM AND PREGNANT DOES AT DIFFERENT AGES

\begin{tabular}{|c|c|c|c|c|c|c|}
\hline \multirow[b]{2}{*}{ Does } & \multirow[b]{2}{*}{$\begin{array}{c}\text { Age } \\
\text { (weeks) }\end{array}$} & \multicolumn{3}{|c|}{ Uterine collagen (based on wet weight) } & \multirow{2}{*}{$\begin{array}{c}\text { Uterine } \\
\text { dry weight } \\
(\%)\end{array}$} & \multirow{2}{*}{$\begin{array}{l}\text { Total collagen } \\
(\% \text { of uterine } \\
\text { dry weight })\end{array}$} \\
\hline & & $\begin{array}{c}\text { Total } \\
\text { uterine } \\
\text { collagen }(g)\end{array}$ & $\begin{array}{c}\text { Alkaline-soluble } \\
\text { collagen } \\
(\mathrm{mg} / \mathrm{g})\end{array}$ & $\begin{array}{l}\text { Acid-soluble } \\
\text { collagen } \\
(\mathrm{mg} / \mathrm{g})\end{array}$ & & \\
\hline \multirow[t]{3}{*}{ Post-partum $†$} & 34 & $14.5 \pm 1.8$ & $\begin{array}{c}2 \cdot 5 \pm 0.8 \\
(\overline{12})\end{array}$ & $\begin{array}{c}17 \cdot 9 \pm 2 \cdot 9 \\
(88)\end{array}$ & $16.9 \pm 0.5$ & $12 \cdot 1 \pm 2 \cdot 0$ \\
\hline & 167 & $22 \cdot 5 \pm 2 \cdot 5$ & $\begin{array}{c}1 \cdot 8 \pm 0 \cdot 2 \\
(11)\end{array}$ & $\begin{array}{c}15 \cdot 2 \div 0 \cdot 8 \\
(8 \overline{9})\end{array}$ & $16 \cdot 4 \pm 0 \cdot 3$ & $10 \cdot 7 \pm 2 \cdot 0$ \\
\hline & 204 & $11 \cdot 0 \pm 1 \cdot 8$ & $\begin{array}{c}6 \cdot 5 \pm 1 \cdot 8^{*} \\
(20)\end{array}$ & $\begin{array}{c}26 \cdot 4 \pm 6 \cdot 4 \\
(80)\end{array}$ & $17 \cdot 3 \pm 0 \cdot 4$ & $22 \cdot 9 \pm 16 \cdot 3$ \\
\hline \multirow[t]{2}{*}{ 12-day pregnant } & 38 & & $\begin{array}{c}1 \cdot 7 \pm 0 \cdot 1 \\
(13)\end{array}$ & $\begin{array}{c}11 \cdot 4 \pm 1 \cdot 6 \\
(87)\end{array}$ & $17.5 \pm 0.6$ & $7 \cdot 6 \pm 1 \cdot 2$ \\
\hline & 174 & $13 \cdot 3 \pm 5 \cdot 0$ & $1 \cdot 7 \pm 0 \cdot 2$ & $\begin{array}{c}16 \cdot 7 \pm 1 \cdot 6^{*} \\
(91)\end{array}$ & $18 \cdot 0 \pm 1 \cdot 8$ & $11 \cdot 1 \pm 2 \cdot 2$ \\
\hline
\end{tabular}

Values expressed as means \pm S.E. Numbers in parentheses are percentages of total collagen.

* Differs significantly from other means of post-partum does in the same column and group $(P<0.05)$.

$\dagger$ Five does/group.

$\ddagger$ Three does/group.

Since the dry-weight fraction of the uterus did not change with age, none of the differences in uterine collagen concentration associated with age appear to be due to changes in water content of the uterus.

Collagen structural changes occur with increased age; this reduces the ability of collagenase to degrade collagen fibres (McGavack \& Kao, 1963; Schaub, 1964, 1964/65, 1965). This structural change in collagen together with the reduction in collagenase could contribute to the higher uterine collagen content of old does. The higher uterine collagen along with lower ovarian progesterone output in old does reported previously (Maurer \& Foote, 1972) may reduce the efficiency of the uterine environment sufficiently to be partly responsible for the increase in embryonic deaths in old does (Maurer \& Foote, 1971). 
This investigation was supported in part by Grant HD 03471 from the National Institute of Child Health and Human Development, USPHS. The authors are grateful to $\mathrm{Mr}$ Bruce Hakes and Mr Michael Simkin for their assistance in collecting the data.

\section{REFERENCES}

Burack, E., Wolfe, J. M., Lansing, W. \& Wright, A. W. (1941) The effect of age upon the connective tissue of the uterus, cervix and vagina of the rat. Cancer Res. 1, 227.

Fins, C. A., Frtch, S. M. \& Harkness, R. D. (1963) Collagen content of barren and previously pregnant uterine horns in old mice. F. Reprod. Fert. 6, 405.

Fitch, S. M., Harkness, M. L. R. \& Harkness, R. D. (1955) Extraction of collagen from tissues. Nature, Lond. 176, 163.

Goodals, F. R. (1965) Degradative enzymes in the uterine myometrium of rabbits under different hormonal conditions. Archs Biochem. Biophys. 112, 403.

Goodall, F. R. (1966) Progesterone retards postpartum involution of the rabbit myometrium. Science, N.Y. 152, 356.

JefrReY, J. J. \& Gross, J. (1970) Collagenase from rat uterus. Isolation and partial characterization. Biochemistry, N.Y. 9, 268.

Kao, K. Y. T. \& MaGavack, T. H. (1959) Connective tissue. I. Age and sex influence on protein composition of rat tissue. Proc. Soc. exp. Biol. Med. 101, 153.

Lowry, O. H., Rosebrough, N. J., FARR, A. L. \& Randall, R. J. (1951) Protein measurements with the folin phenol reagent. F. biol. Chem. 193, 265.

McGavack, T. H. \& KAo, K. Y. T. (1963) Ageing in connective tissue: a dynamic process. F. Am. Geriat. Soc. 11, 1024.

MANDL, I., MACLENNAN, J. D. \& Howes, E. L. (1953) Isolation and characterization of proteinase and collagenase from Cl. histolyticum. F. clin. Invest. 32, 1323.

MaURer, R. R. \& Foote, R. H. (1971) Maternal ageing and embryonic mortality in the rabbit. I. Repeated superovulation, embryo culture and transfer. F. Reprod. Fert. 25, 329.

Maurer, R. R. \& Foote, R. H. (1972) Maternal ageing and embryonic mortality in the rabbit. II. Hormonal changes in young and ageing females. $\mathcal{F}$. Reprod. Fert. 31 (In press).

Neuman, R. E. \& Logan, M. A. (1950) The determination of collagen and elastin in tissues. F. biol. Chem. 186, 549 .

Ryan, J. N. \& Woessner, J., JR (1971) Mammalian collagenase. Direct demonstration in homogenates of involuting rat uterus. Biochem. biophys. Res. Commun. 44, 144.

Prockop, D. J. \& Udenfriend, S. (1960) A specific method for the analysis of hydroxyproline in tissues and urine. Analyt. Biochem. 1, 228.

Schaub, M. C. (1964) Distribution and variation of a collagen degrading enzyme in the uterus of pregnant rats. Experientia, 20, 675.

Schaub, M. C. (1964/65) Changes of collagen in the ageing and in the pregnant uterus of white rats. Gerontologia, 10, 137.

Schaur, M. C. (1965) Die Wirkung von Kathepsin auf Kollagen und Casein im graviden und nichtgraviden Uterus der Ratte. Hoppe-Seyler's Z. physiol. Chem. 343, 130.

Worssner, J. F., JR (1962) Catabolism of collagen and non-collagen protein in the rat uterus during post-partum involution. Biochem. F. 83, 304.

WOESSNER, J. F., JR (1969) Inhibition by oestrogen of collagen breakdown in the involuting rat uterus. Biochem. F. 112, 637.

WüNsch, E. \& HeIDRIch, H. G. (1963) Zur quantitativen Bestimmung der Kollagenase. Hoppe-Seyler's Z. physiol. Chem. 333, 149. 